\title{
ВПЛИВ ОБРОБКИ ЗАХИСНИМИ ПРЕПАРАТАМИ НА ОСНОВІ КОМПЛЕКСІВ «ХІТОЗАН-МІДЬ» НА ЗМЕНШЕННЯ МАСИ ХАРЧОВИХ КУРЯЧИХ ЯЄЦЬ ПРОТЯГОМ ЗБЕРІГАННЯ
}

\author{
Чех Олександр Олександрович \\ аспірант \\ Сумський національний аграрний університет \\ ORCID: 0000-0002-8947-5269 \\ E-mail: olexa0701@mgmail.co
}

Бордунова Ольга Георгіївна доктор сільськогосподарських наук, профресор Сумський національний аграрний університет ORCID: 0000-0002-7120-1040 E-mail: bordunova.olga59@gmail.com

Чиванов Вадим Дмитрович кандидат біологічних наук, доцент Інститут прикладної фізики, Суми

ORCID: 0000-0001-5845-2315 E-mail:vadym58@gmail.com

У роботі представлено способи обробки харчових курячих яєць. Відбиралися свіжі знесені яйця категорії С0 65-75 г породи «Декалб-Уайт». Зберігали в чистих лотках по 30 штук у кожному. Яйця були розділені на VII груп і зберігалися при температурі $21^{\circ} \mathrm{C}$. Зберігання яєць при кімнатній температурі призводить до погіршення якісних органолептичних показників вмісту яйця, збільшення швидкості проникнення і розмноження Escherichia coli, Staphylococcus aureus, Salmonella enterica, БГКП (бактерій групи кишкових паличок) у порівнянні з яйцями, що зберігалися у холодильних камерах при температурі до $8^{\circ} \mathrm{C}$. Метою роботи було визначення впливу обробки харчових яєць курей захисними препаратами на основі комплексів «хітозан-мідь» на зменшення маси харчових курячих яєиь протягом зберігання. Формували сім партій курячих яєць по 30 шт. в кожній. Дослідні партії обробляли захисними препаратами комплексів "Хітозан-мідь», приготованими різними способами. Дослід проводився протягом 30 днів. Яйия курячі розподіляли на окремі групи. 3 метою ізоляції вмісту яєць курячих харчових від впливу зовнішнього середовища, зменшення втрат маси та запобігання мікробного забруднення нами було застосовано обробку поверхні шкаралупи кожного яйця різними речовинами. Наведений склад композиції для обробки харчових курячих яєць на основі комплексів «Хітозан-мідь» із захисту від патогенної мікрофрлори бактеріального і вірусного походження гальмує втрату маси яєць протягом усього терміну зберігання. В дослідній групі, де курячі яйця обробляли Розчином (5), до складу якого входять водний хітозан (2-5\%) з додаванням надоцтової та оитової кислоти (1:1 за об'ємом) і підданий електролізу із застосуванням титану у якості аноду та катоду, вага яєць зменшилася на 1,3 \%, 2,4 \% на 14 день, 3,1 \% на 21 день, 7,5\% на 30 добу, що показало найкращий результат. Таким чином на зменшення маси курячих яєць впливає не тільки температура зберігання, а й захисні препарати на основі комплексів "хітозан-мідь», що показали зменшення швидкості втрати ваги і псування яєць під час зберігання при температурі $21^{\circ} \mathrm{C}$. Розроблена «зелена» електрохімічна технологія синтезу захисних покрить для харчових яєць для подовження терміну зберігання/транспортування на основі комплексів типу «хітозан-мідь»; 2) Експериментально доведено, що використання технології захисту харчових яєць курей, що базується на утворенні на поверхні яєць тонкошарового покриття з екологічно безпечного хітозану, до складу якого входять іони міді, не здійснюють статистично вірогідного впливу на зменшення маси яєць у порівнянні з контролем.

Ключові слова: технологія, харчові яйця, дезінфекція, хітозан, електроліз

DOl: https://doi.org/10.32845/bsnau.lvst.2020.4.18

Питання тривалого зберігання яєць із гарантованими характеристиками якості та безпечності залишається актуальним. Якщо технологічні режими зберігання давно увійшли до світових стандартів, то питання санітарної обробки яєць перед зберіганням залишається спірним. Національний стандарт на харчові курячі яйця обмежує зберігання в холодильнику митих яєць до 12 діб, тоді як в Сполучених Штатах Америки, Австралії, Японії миття курячих яєць перед зберіганням визнано обов'язковою процедурою [3].

Висока поживна та біологічна цінність курячих яєць $€$ важливим і доступним джерелом повноцінного тваринного білка, який легко засвоюється організмом людини. Харчові курячі яйця є продуктом збалансованого, високоякісного, з

великим вмістом амінокислот білку, а також жирів, вітамінів, мінералів тощо, що має попит у населення. Актуальним $\epsilon$ питання безпечності та якості харчового яйця. Тривале зберігання курячих яєць забезпечує природна будова та хімічний склад, але при цьому потрібно враховувати багато факторів (годівлю курей, вік несучок, породу, напрям продуктивності, температуру та відносну вологість під час зберігання, ступінь забруднення яєчної шкаралупи), що впливають у підсумку на якість яйця [5]. Світовими стандартами передбачені практично усі можливі технології зберігання харчових яєць, проте вживані у різних країнах світу режими оброблення яєць (миття, нанесення захисних покрить) до цього часу являють предмет палких дискусій.

Вісник Сумського національного аграрного університету 
Температура зберігання яєць є важливим фактором, що впливає на якість і вміст, поживну цінність продукту. Вплив температури під час зберігання на якість і безпечність яєць підтверджено різними вченими. Зберігання яєць при кімнатній температурі призводить до погіршення якісних органолептичних показників вмісту яйця, збільшення швидкості проникнення і розмноження Escherichia coli, Staphylococcus aureus, Salmonella enterica, БГКП (бактерій групи кишкових паличок) у порівнянні з яйцями, що зберігалися у холодильних камерах при температурі до $8^{\circ} \mathrm{C}$ $[5,7,13]$.

Щойно знесене, свіже яйце досить швидко втрачає свої властивості. Найбільш поширеним способом $€$ зберігання курячих яєць свіжими при низьких температурах у холодильних шафах. Сьогодні зусилля спеціалістів у даній галузі направлені на пошук способів більш тривалого зберігання яєць зі збереженням корисних якостей.

Вважається, що миття яєць порушує структуру надшкаралупної плівки (кутикули), яка є першою лінією захисту на непошкодженому яйці від проникнення через пори шкаралупи мікроорганізмів. Проте, ця позиція в одних дослідженнях спростовується, а в інших підтверджується. Також не варто нехтувати фактом, що миття яєць із дотриманням необхідних процедур обробки в рази зменшує мікробне забруднення шкаралупи $[9,10,11,12,15]$.

Для захисту вмісту яєць від зовнішнього середовища, а також зменшення втрат маси при зберіганні випробувано покриття шкаралупи яєць різними засобами. Найчастіше для обробки поверхні яєць застосовують формалін, мінеральні легкі масла, оскільки вони менш текучі й швидше проникають у пори шкаралупи. Закупорюючи їх, масло запобігає не тільки випаровуванню вологи, а й втратам вуглекислого газу, що сповільнює всі процеси, пов'язані зі старінням яєць (зміна рН білка, його розрідження, ослаблення градинок і жовткової оболонки тощо). Ефективною є обробка яєць шляхом обприскування надоцтовою кислотою (НОК). При цьому відбувається дезінфекція поверхні шкаралупи яєць і ущільнення підшкаралупних плівок, не змінює товарного вигляду яєць і не впливає на їх смакову якість. [1,2].

Харчова цінність курячих яєць, хімічний склад і властивості нажаль не $є$ постійними. Вони змінюються при зберіганні залежно від умов та строку. 3 першого дня зберігання спостерігається всихання, тобто втрата маси яйця шляхом випаровування вологи з нього у навколишнє середовище.

В результаті випаровування води маса і вміст яйця зменшується, водночас збільшується розмір повітряної камери. Зміна розміру повітряної камери свідчить про зниження ступеня свіжості яєць. Інтенсивність всихання залежить від мікробіологічного забруднення шкаралупи яєць, температури та вологості повітря приміщення в якому зберігаються яйця. При старінні яєць спостерігаються такі фізичні зміни, як переміщення води з білка в жовток та переміщення жовтка. До біохімічних процесів, які мають місце при тривалому зберіганні яєць, відносять складні зміни, що відбуваються у білку та жовтку під впливом власних ферментів (розрідження білка, зміна жиру тощо). Процеси, що протікають при тривалому зберіганні яєць знижують їх якість, а в окремих випадках $€$ причиною непридатності їх для споживання людиною. Зміни в харчових яйцях можуть бути зумовлені розвитком мікроорганізмів і при недотриманням умов зберігання, що є причиною їх псування. Свіжознесені яйця, як правило, стерильні. Зараження мікроорганізмами відбувається в основному після знесення екзогенним шляхом через шкаралупу та підшкаралупну оболонку. Для зберігання курячих яєць необхідно створити такі умови, які б запобігали проникненню всередину мікроорганізмів та їх подальшому розвитку, затримували фрізичні та біохімічні процеси в середині яйця й уповільнювали його псування [16].

Якість яєць можна оцінити за допомогою фізичних, хімічних, біологічних та функціональних характеристик. Такі фактори, як вік та живлення несучок, температура, вологість повітря, умови та час зберігання впливають на якість яєць. Деякі зміни білка та жовтка перевіряються протягом зберігання. Серед хімічних реакцій, що відбуваються всередині яєць, $є$ перетворення білка із щільного в рідкий. Ця зміна, можливо, стосується газу $\mathrm{H}_{2} \mathrm{CO}_{3}$, одним із компонентів буферної системи білка, який дисоціюється у воду та $\mathrm{CO}_{2}$. Відбувається зменшення загального вмісту твердих речовин у білках. Також спостерігається збільшення рН та зменшення маси яйця. Отже, під час зберігання внутрішня якість яєць може визначатися збільшенням рН білка, зменшенням маси яєць та зменшенням загального вмісту твердих речовин білка $[5,6,17]$.

Певних перспектив набули технології покриття поверхні харчових яєць штучними композитними покриттями на основі екологічно безпечних речовин. До таких відноситься хітозан. Останнім часом увага дослідників прикута до «зелених» технологій синтезу препаратів для проведення боротьби зі хвороботворними агентами (бактерій, вірусів). До таких «зелених» технологій 3 певними обмеженнями належить електрохімічний синтез. Хітозанові мідні комплекси приготовані з різними концентраціями міді за допомогою електрохімічного методу окислення у водно-оцтовому середовищі. Його проводили при постійній напрузі (2 вольта) при кімнатній температурі та різному часі електроокислення.

Таким чином, метою даного дослідження $€$ визначення впливу обробки харчових яєць курей захисними композиціями на основі комплексів «хітозан-мідь» на зменшення маси харчових курячих яєць протягом зберігання [3,14]

Матеріали та методи досліджень. Дослідження проводились в лабораторії кафедри біохімії та біотехнології Сумського національного аграрного університету. Для проведення досліджень відібрали яйця курячі свіжі столові категорії С0 65-75 г породи «Декалб-Уайт». Яйця зберігали в чистих коробках по 30 штук у кожній. Яйця були розділені на VII груп і зберігалися при температурі $21^{\circ} \mathrm{C}$.

Досліджували якість харчових яєць зовнішнім оглядом, приділяли увагу стану шкаралупи. Важливим фактором $€$ маса одного яйця, яку визначали зважуванням, Визначали стан висоти повітряної камери, білка і жовтка методом овоскопування. При дослідженні запаху звертали увагу на наявність стороннього і невластивого курячому яйцю. Яйця курячі розподіляли на окремі групи. 3 метою ізоляції вмісту яєць курячих харчових від впливу зовнішнього середовища, зменшення втрат маси та запобігання мікробного забруднення нами було застосовано обробку поверхні шкаралупи кожного яйця різними речовинами.

В роботі використовували порошок хітозану, $\mathrm{Mw}=$ 600000 г / моль і ступінь деацетилювання становить $75 \%$ (Aldrich-Sigma), оцтову та надоцтову кислоти (х. ч.), деіонізовану воду. Мідні та титанові пластинки (10 мм, 60 мм, 1 мм; 99,995\% чистоти) використовували у якості як аноду так 
і катоду, в залежності від різновиду досліду. Комплекси «хітозан-мідь» отримували електрохімічним окисленням металу у водних кислотних середовищах. Експериментальна установка, що застосовувалась для приготування ком- плексів «хітозан-мідь» складалась 3 металевих платівок (анод та катод), занурених на 4 см у електролітичний розчин на відстані 2 см один від одного. Сполучені платинові дроти були підключені до джерела постійної напруги (Рис. 1).

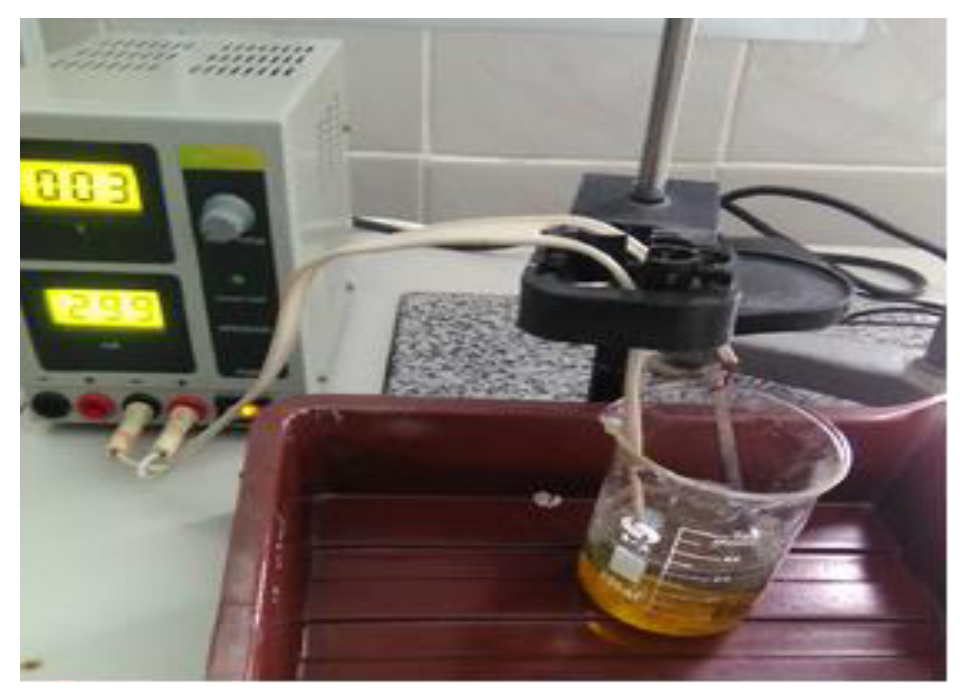

Рис. 1. Установка для проведення електрохімічного синтезу препаратів на основі комплексів «хітозан-мідь».

Експерименти проводили з різним часом електроокислення розчину хітозану у кислотному водному середовищі $\left(1,5\right.$ - 10 годин; водяна баня, $\left.25^{\circ} \mathrm{C}\right)$.

Для обробки шкаралупи харчових яєць використовували такі композиції:

Розчин (0). Створений на основі водного 2-5\% хітозану з додаванням надоцтової та оцтової кислоти (1:1 за об'ємом) і підданого електролізу із застосуванням міді у якості катоду та титану у якості аноду.

Розчин (1). Водний 2-5\% хітозан 3 додаванням надоцтової, оцтової та сірчаної кислот (1:1:0,05 за об'ємом) і підданий електролізу із застосуванням міді у якості катоду та титану у якості аноду.

Розчин (2). Водний 2-5\% хітозан 3 додаванням надоцтової та оцтової кислот (1:1 за об'ємом) і підданий електролізу із застосуванням міді у якості катоду та аноду.

Розчин (3). Водний 2-5\% хітозан 3 додаванням надоцтової та оцтової кислоти (1:1 за об'ємом) і підданий електролізу із застосуванням міді у якості аноду та титану у якості катоду.
Розчин (4). 5\% водний розчин надоцтової кислоти (HOK)

Розчин (5). Водний 2-5\% хітозан 3 додаванням надоцтової та оцтової кислоти (1:1 за об'ємом) і підданий електролізу із застосуванням титану у якості аноду та катоду

Для обробки яєць використовували водний робочий розчин, який готували розбавлянням до 20 мас. частин 1 мас. частини розчинів (0) - (5). Ретельно перемішували і наносили на поверхню яєць розприскувачем, що здатен забезпечити діаметр часток рідкофазового аерозолю 5-8 мКм.

Контролем слугували необроблені яйця.

Статистичну обробку результатів експериментів проводили за допомогою пакету Statistica 7.0.

Результати досліджень. В таблиці 1 представлені дані щодо зміни маси яєць, котрі були оброблені різними розчинами, як зазначено у розділі в «Матеріали та методика досліджень».

Зміна маси оброблених композиціями курячих яєць породи «Декалб-Уайт»

Таблиця 1 при зберіганні протягом 30 діб, $n=210, \overline{X \pm} S_{\bar{x}}$

\begin{tabular}{|c|c|c|c|c|c|}
\hline \multirow{2}{*}{ Групи } & \multicolumn{5}{|c|}{ Середня вага яєць, г } \\
\cline { 2 - 5 } & При закладці & 6 днів & 14 днів & 21 день & 30 день \\
\hline $\begin{array}{c}\text { Контрольна } \\
\text { група }\end{array}$ & $62,53 \pm 1,322$ & $61,19 \pm 1,053$ & $60,03 \pm 0,834$ & $59,34 \pm 0,714$ & $55.17 \pm 0,452$ \\
\hline Розчин (0) & $68,23 \pm 2,514$ & $66,73 \pm 2,704$ & $65,48 \pm 2,799$ & $64,71 \pm 2,860$ & $58,49 \pm 2,976$ \\
\hline Розчин (1) & $63,68 \pm 2,525$ & $62,48 \pm 2,541$ & $61,44 \pm 2,594$ & $60,83 \pm 2,614$ & $57,54 \pm 2,866$ \\
\hline Розчин (2) & $65,13 \pm 3,671$ & $63,86 \pm 3,714$ & $62,76 \pm 3,805$ & $62,1 \pm 3,392$ & $58,25 \pm 4,234$ \\
\hline Розчин (3) & $63,87 \pm 1,162$ & $62,73 \pm 1,259$ & $61,75 \pm 1,348$ & $61,17 \pm 1,395$ & $57,68 \pm 1,697$ \\
\hline Розчин (4) & $63,75 \pm 1,316$ & $62,81 \pm 1,281$ & $61,99 \pm 1,242$ & $61,48 \pm 1,229$ & $58,36 \pm 1,135$ \\
\hline Розчин (5) & $63,72 \pm 3,548$ & $62,89 \pm 3,594$ & $62,15 \pm 3,609$ & $61,69 \pm 3,612$ & $58,91 \pm 3,649$ \\
\hline
\end{tabular}

Примітка: в усіх варіантах у порівнянні р>0,05

Як ми можемо спостерігати за даними в таблиці 1, у жодній групі не виявлено достовірного впливу досліджуваних препаратів на зменшення середньої ваги яєць, проте в усіх групах спостерігалася тенденція до зменшення даного показника. В контрольній групі середня вага яєць зменшилася на 2,1 \% в 6 день, на 4\% в 14 день, 5,1 \% в 21 день та 
11,7 \% на 30 день дослідження. В групі де були курячі яйця оброблені Розчином (0) вага яєць зменшилася на 2,1 \% в 6 день на 4 \%, 5,1\% на 21 день та на 30 14,2 \%. В групі де курячі яйця були оброблені Розчином (1), їх вага зменшилася на 1,8 \% в 6 день, 3,5 \% на 14 день, 4,4 \% в 21 день та на $9 \% 3$ у 30 день. В групі, де яйця були оброблені Розчином (2) вага яєць зменшилася на 1,9\% в 6 день, 3,6 \% в 14 день, 21 день 4,6 \% і на 30 добу 10,5 \%. В групі де був задіяний
Розчин (3) вага яєць зменшилася на 1,7 \% в 6 день, 3,3 \% на 14 день, в 21 день їх маса зменшилася на 4,2 \% та 9,6 \% на 30 добу. В іншій групі де яйця обробляли Розчином (4) вага яєць зменшилася 1,4 \% на 6 день, 2,7 \% на 14 день, 3,5 \% в 21 день та 9,1\% на 30 день. В дослідній групі, де курячі яйця обробляли Розчином (5) вага яєць зменшилася на 1,3 $\%, 2,4 \%$ на 14 день, 3,1\% на 21 день, 7,5\% на 30 добу, що показало найкращий результат.

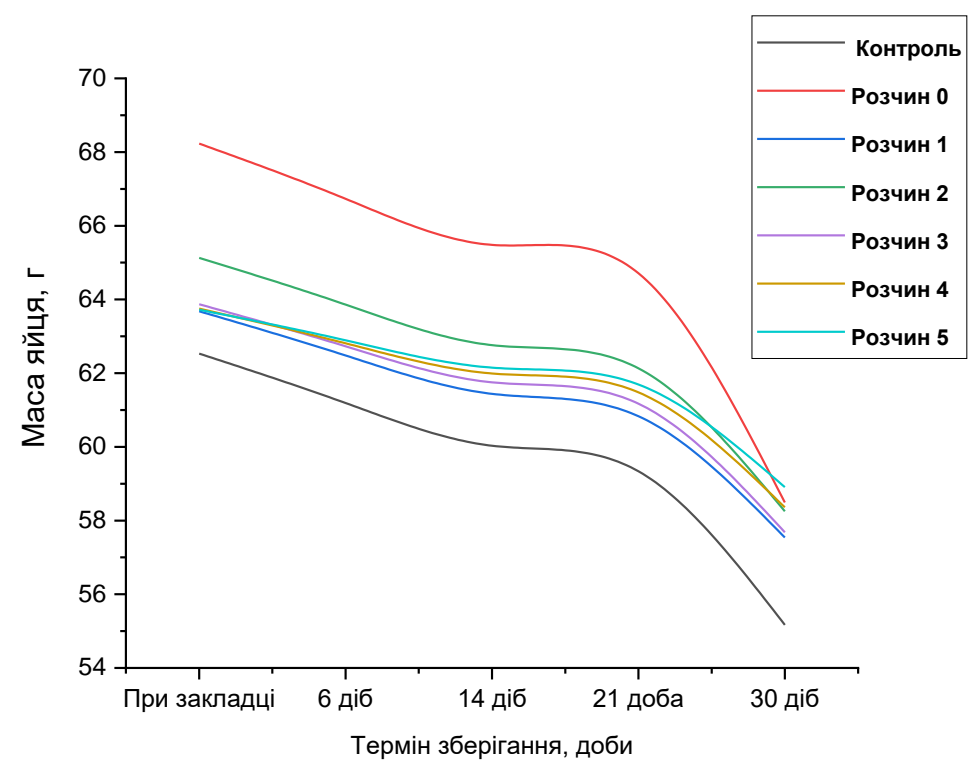

Рис. 2. Часова динаміка змін маси контрольних та оброблених композиціями «хітозан-мідь» яєць, що зберігались протягом 30 діб при температурі $21^{\circ} \mathrm{C}$

3 рис. 2 можна бачити, що в усіх варіантах і у контролі спостерігалась наявність плато у масі яєць 14-21 доба зберігання.

Висновки. 1) Розроблена «зелена» електрохімічна технологія синтезу захисних покрить для харчових яєць для подовження терміну зберігання/транспортування на основі комплексів типу «хітозан-мідь»;

2) Експериментально доведено, що використання технології захисту харчових яєць курей, що базується на утворенні на поверхні яєць тонкошарового покриття з екологічно безпечного хітозану, до складу якого входять іони міді, не здійснюють статистично вірогідного впливу на зменшення маси яєць у порівнянні з контролем.

Подяки. Робота виконана за фінансової підтримки Міністерства освіти і науки України (номер державної реєстрації 0119U100551).

\section{Список використаної літератури}

1. Астраханцева О. Г., Самохіна Є. А., Бордунова О. Г., Чіванов В.Д.Композиція для захисту інкубаційних яєць курей на основі хітозану, перекисних сполук і сульфрату заліза (FeSO4 5H2O). Вісник Сумського національного аграрного університету. Серія: «Тваринництво». Суми: СНАУ, 2016. Bun.(7). С. 207-213.

2. Штеле А. Фисинин В., Ерастов Г. Качество пищевых яиц и здоровое питание. Птицеводство, 2008, Т 2, С. 2-6.

3. Ayman S. Elmezayyen, Fikry M. Reicha. Preparation of Chitosan copper complexes: Molecular dynamic studies of Chitosan and Chitosan copper complexes. Open Journal of Applied Sciences Vol.05 No.08(2015), Article ID:58545,12 pages 10.4236/ojapps.2015.58041.

4. Alleoni A.C. C., Antunes A.J. Unidade Haugh como medida da qualidade de ovos de galinha armazenados sob refrigeração. Sci. Agric., 2001. Issue 8, pp. 681-685.

5. Al-Natour M. Q., Alaboudi A. R., Al-Hatamelh N. A., and Osaili T. M. Escherichia coli 0157:H7 Facilitates the Penetration of Staphylococcus aureus into Table Eggs. Journal of Food Science, 2011. Issue 77(1), pp. 29-34.

6. Brake J., Walsh T.J., Benton C. E. Jr., Petitte J. N., Meijerhof R., Peñalva G. Egg handling and storage. Poult. Sci., 1997. Issue 76, pp. 144-151.

7. Figueiredo T. C., Cançado S. V., Viegas R. P., Rêgo I. O. P., Lara L. J. C., Souza M. R. and Baião N. C. Qualidade de ovos comerciais submetidos a diferentes condições de armazenamento. Arquivo Brasileiro de Medicina Veterinária e Zootecnia, 2011. Issue 63(3), pp. 712-720.

8. Figueiredo T. C., Viegas R. P., Lara L. J. C., Baiao N. C., SouzaM. R., Heneine L. G. D., andCancado S. V. Bioactive amines and internal quality of commercial eggs. Poultry Science, 2013. Issue 92(5), pp. 1376-1384.

9. Gole V. C., Roberts J. R., Sexton M., May D., Kiermeier A. and Chousalkar K. K. Effect of egg washing and correlation between cuticle and egg penetration by various Salmonella strains. International Journal of Food Microbiology, 2014. Issue 182-183, 
pp. 18-25.

10. Jones D. R., et al. Impact of egg handling and conditions during extended storage on egg quality.Poultry science, 2018.Issue 97(2), pp.716-723.

11. Leleu S., Messens W., De Reu K., De Preter S., Herman L., Heyndrickx M., and Bain M. Effect of egg washing on the cuticle quality of brown and white table eggs. Journal of Food Protection,2011. Issue 74(10), pp. 1649-1654.

12. Liu Y.-C., Chen T.-H., Wu Y.-C., Lee Y.-C., and Tan F.-J. Effects of egg washing and storage temperature on the quality of eggshell cuticle and eggs. Food Chemistry, 2016. Issue 211, pp. 687-693.

13. Lublin A., Maler I., Mechani S., Pinto R., and Sela-Saldinger S. Survival of Salmonella enterica serovar infantis on and within stored table eggs. Journal of Food Protection, 2015. Issue 78(2), pp. 287-292.

14. Gritsch L., Lovell C., Goldmann W. H., Boccaccini A. R. Fabrication and characterization of copper(II)-chitosan complexes as antibiotic-free antibacterial biomaterial. Carbohydrate Polymers, 2018 Volume 179, 1 January, pp. 370-378 https://doi.org/10.1016/j.carbpol.2017.09.095.

15. Samiullah K., Chousalkar K. K., Roberts J. R., Sexton M., May D., and Kiermeier A. Effects of eggs shell quality and washing on Salmonella infant is penetration. International Journal of Food Microbiology, 2013. Issue 165(2), pp. 77-83.

16. Shevchik R. S., KunevaL. V., and Samoyluk G. V. Influence of methods of processing and storage on qualitative indices of food chicken eggs. Theoretical and Applied Veterinary Medicine ,2019. Issue 7(2), pp. 69-73. doi: 10.32819/2019.71012.

17. Xavier I. M. C., Cançado S.V., Figueiredo T. C., Lara L. J. C., Lana A. M. Q., Soua M. R., Baião N.C. Qualidade de ovos de consumo submetidos a diferentes condições de armazenamento. Arq. Bras. Med. Vet. Zootec., 2008. Issue 60, pp. 953959.

\section{References}

1. Astrakhantseva, O. H., Samokhina, Ye. A., Bordunova, O. H. and Chivanov, V. D., 2016. Kompozytsiia dlia zakhystu inkubatsiinykh yaiets kurei na osnovi khitozanu, perekysnykh spoluk i sulfatu zaliza ( $\mathrm{FeSO} 45 \mathrm{H} 2 \mathrm{O}$ ) [Composition for protection of hatching eggs of chickens based on chitosan, peroxide compounds and ferrous sulfate (FeSO4 5H2O)]. Visnyk Sumskoho natsionalnoho ahrarnoho universytetu. Seriia: «Tvarynnytstvo». Sumy: SNAU, issue (7), pp. 207-213.

2. Shtele, A. Fisinin V. and Erastov, G., 2008. Kachestvo pischevyih yaits i zdorovoe pitanie [Egg quality and healthy eating]. Ptitsevodstvo, issue (2), pp. 2-6.

3. Ayman, S. Elmezayyen, Fikry, M. Reicha 2015. Preparation of Chitosan copper complexes: Molecular dynamic studies of Chitosan and Chitosan copper complexes. Open Journal of Applied Sciences Vol.05 No.08, Article ID:58545,12 pages 10.4236/ojapps.2015.58041.

4. Alleoni, A. C. C. and Antunes, A. J., 2001. Unidade Haugh como medida da qualidade de ovos de galinha armazenados sob refrigeração. Sci. Agric., issue (8), pp. 681-685.

5. Al-Natour, M. Q., Alaboudi, A. R., Al-Hatamelh, N. A. and Osaili, T. M., 2011. Escherichia coli 0157:H7 Facilitates the Penetration of Staphylococcus aureus into Table Eggs. Journal of Food Science, issue 77(1), pp. 29-34.

6. Brake, J., Walsh, T. J., Benton, C. E. Jr., Petitte, J. N., Meijerhof, R. and Peñalva, G., 1997. Egg handling and storage. Poult. Sci., issue (76), pp. 144-151.

7. Figueiredo, T. C., Cançado, S. V., Viegas, R. P., Rêgo, I. O. P., Lara, L. J. C., Souza, M. R. and Baião, N. C., 2011. Qualidade de ovos comerciais submetidos a diferentes condições de armazenamento. Arquivo Brasileiro de Medicina Veterinária e Zootecnia, issue 63(3), pp.712-720.

8. Figueiredo, T. C., Viegas, R. P., Lara, L. J. C., Baiao, N. C., Souza, M. R., Heneine, L. G. D. and Cancado, S. V., 2013. Bioactive amines and internal quality of commercial eggs. Poultry Science, issue 92(5), pp.1376-1384.

9. Gole, V. C., Roberts, J. R., Sexton, M., May, D., Kiermeier, A. and Chousalkar, K. K., 2014. Effect of egg washing and correlation between cuticle and egg penetration by various Salmonella strains. International Journal of Food Microbiology, issue (182-183), pp. 18-25.

10. Jones, D. R., Ward, G. E., Regmi, P., and Karcher, D. M. 2018. Impact of egg handling and conditions during extended storage on egg quality. Poultry science, issue 97(2), pp. 716-723.

11. Leleu, S., Messens, W., De Reu, K., De Preter, S., Herman, L., Heyndrickx, M. and Bain, M., 2011. Effect of egg washing on the cuticle quality of brown and white table eggs. Journal of Food Protection, issue74(10), pp. 1649-1654.

12. Liu, Y.-C., Chen, T.-H., Wu, Y.-C., Lee, Y.-C. and Tan, F.-J., 2016. Effects of egg washing and storage temperature on the quality of eggshell cuticle and eggs. Food Chemistry, issue 211, pp. 687-693.

13. Lublin, A., Maler, I., Mechani, S., Pinto, R. and Sela-Saldinger, S., 2015. Survival of Salmonella enterica serovar infantis on and within Stored Table Eggs. Journal of Food Protection, issue 78(2), pp. 287-292.

14. Gritsch, L., Lovell, C., Goldmann, W. H. and Boccaccini, A. R., 2018. Fabrication and characterization of copper(II)chitosan complexes as antibiotic-free antibacterial biomaterial. Carbohydrate Polymers issue (179), 1 January, pp. 370-378 https://doi.org/10.1016/i.carbpol.2017.09.095.

15. Samiullah, K., Chousalkar, K. K., Roberts, J. R., Sexton, M., May, D. and Kiermeier, A., 2013. Effects of eggs shell quality and washing on Salmonella infant is penetration. International Journal of Food Microbiology, issue 165(2), pp. 77-83.

16. Shevchik, R. S., Kuneva, L. V. and Samoyluk, G. V., 2019. Influence of methods of processing and storage on qualitative indices of food chicken eggs. Theoretical and Applied Veterinary Medicine, issue 7(2), pp. 69-73. doi: 10.32819/2019.71012.

17. Xavier, I. M. C., Cançado, S. V., Figueiredo, T. C., Lara, L. J. C., Lana, A. M. Q, Soua, M. R. and Baião, N.C., 2008. Qualidade de ovos de consumo submetidos a diferentes condições de armazenamento. Arq. Bras. Med. Vet. Zootec., issue 60, pp. 
953-959.

Chekh Oleksandr Oleksandrovich, PhD student, Sumy National Agrarian University (Sumy, Ukraine) Ukraine)

Bordunova Olga Georgievna, Doctor of Agricultural Sciences, Proffesor, Sumy National Agrarian University (Sumy, Ukraine)

Chivanov Vadym Dmytrovich, Candidate of Biological Sciences, Associate Professor, Institute of Applied Physics (Sumy,

Influence of protection with protective drugs based on chitosan-copper complexes on reduction of weight of food chicken eggs during storage

The paper presents methods of processing edible chicken eggs. Fresh demolished eggs of category C0 65-75 g of breed "Decalb-White" were selected. Stored in clean boxes of 30 piece each. The eggs were divided into groups VII and stored at $21^{\circ} \mathrm{C}$. Storage of eggs at room temperature leads to deterioration of quality organoleptic characteristics of egg content, increased rate of penetration and reproduction of Escherichia coli, Staphylococcus aureus, Salmonella enterica, BGKP (bacteria of the Escherichia coli group) in comparison with eggs stored in refrigerators. The aim of the study was to determine the effect of treatment of edible chicken eggs with protective drugs based on "chitosan-copper" complexes on reducing the weight of edible chicken eggs during storage. Formed seven batches of chicken eggs of 30 pieces. in every. The experimental batches were treated with protective drugs of Chitosan-copper complexes, prepared in different ways. The experiment was performed for 30 days. Chicken eggs were divided into separate groups. In order to isolate the content of chicken eggs from the environment, reduce weight loss and prevent microbial contamination, we used the treatment of the surface of the shell of each egg with different substances. The composition of the composition for processing edible chicken eggs on the basis of complexes "Chitosan-copper" for protection against pathogenic microflora of bacterial and viral origin inhibits the loss of egg weight throughout the shelf life. In the experimental group, where chicken eggs were treated with Solution (5), which consists of aqueous chitosan (2-5\%) with the addition of peracetic and acetic acid (1: 1 by volume) and subjected to electrolysis using titanium as an anode and cathode, egg weight decreased by $1.3 \%, 2.4 \%$ on day 14 , $3.1 \%$ on day $21,7.5 \%$ on day 30 , which showed the best result. Thus, the decrease in the weight of chicken eggs is influenced not only by the storage temperature, but also by protective preparations based on chitosan-copper complexes, which showed a decrease in the rate of weight loss and spoilage of eggs during storage at $21^{\circ} \mathrm{C}$. Developed "green" electrochemical technology for the synthesis of protective coatings for food eggs to extend the shelf life / transportation on the basis of complexes such as "chitosancopper"; 2) It is experimentally proven that the use of technology for protection of eggs for laying chickens, based on the formation on the surface of eggs of a thin layer of environmentally friendly chitosan, which contains copper ions, does not have a statistically significant effect on egg weight reduction compared to control.

Key words: technology, food eggs, disinfection, chitosan, electrolysis

Дата надходження до редакції: 16.11 .2020 р. 